\title{
KONTRIBUSI PEMBELAJARAN TUTORIAL BERBASIS ARTICULATE ONLINE TERHADAP AKTIVITAS DAN KETERAMPILAN PERAKITAN KOMPUTER
}

\author{
Iman Nasrulloh
}

\section{ABSTRAK}

Penelitian ini berjudul "Kontribusi Penggunaan Model Pembelajaran Tutorial Berbasis Articulate Online Terhadap Aktifitas Dan Keterampilan Siswa Dalam Perakitan Komputer". Masalah dalam penelitian ini penulis rumuskan sebagai berikut: :'Berapa besarnya kontribusi penggunaan model pembelajaran tutorial berbasis articulate online terhadap aktifitas dan keterampilan siswa dalam perakitan komputer". Berdasarkan rumusan masalah tersebut tujuan penelitian ini adalah untuk mengetahui ada/tidaknya kontribusi penggunaan model pembelajaran tutorial berbasis articulate online terhadap aktifitas dan keterampilan siswa dalam perakitan komputer. Dari permasalah yang diangkat dalam penelitian ini penulis menurunkan hipotesis :" Terdapat kontribusi yang signifikan dan positif kontribusi penggunaan model pembelajaran tutorial berbasis articulate online terhadap aktifitas dan keterampilan siswa dalam perakitan komputer". Metode yang digunakan dalam penelitian ini adalah metode korelasional, yakni metode yang bertujuan untuk menyelidiki variasi yang dimiliki suatu faktor berhubungan dengan variasi pada faktor - faktor lainnya pada satu kelompok subjek yang didasarkan pada koefisien korelasi. Instrumen yang digunakan untuk memperoleh dengan angket dan tes objektif dalam bentuk pilihan ganda dan menjodohkan yang diisi oleh siswa. Penelitian ini dilakukan di SMK Al-Farizi Kelas X-1 Jurusan TKJ dengan sampel sebanyak satu kelas. Pengolahan data yang digunakan adalah dengan menggunakan perhitungan statistik korelasi product moment dan uji signifikansi korelasi dengan uji-t. Pengujian hipotesis dilakukan dengan cara membandingkan nilai $t_{\text {hitung }}$ dengan $t_{\text {tabel }}$ pada taraf kepercayaan 95\% dengan derajat kebebasan $(\mathrm{dk})=36$. Berdasarkan hipotesis dan analisis data yang telah dilakukan, diperoleh kesimpulan bahwa : (1) Kontribusi penggunaan model pembelajaran tutorial berbasis articulate online terhadap aktifitas dan keterampilan siswa dalam perakitan komputer adalah baik sekali, karena skor rata-rata yang diperoleh 63,47 (85\%). (2) Keterampilan siswa yang menggunakan model pembelajaran tutorial berbasis articulate online terhadap aktifitas dan keterampilan siswa dalam perakitan komputer di SMK Al-Farizi adalah baik, skor rata-rata yang diperoleh 18,79 (72\%). (3) Kontribusi penggunaan model pembelajaran tutorial berbasis articulate online terhadap aktifitas dan keterampilan siswa dalam perakitan komputer adalah 42,9\%, sisanya sebanyak $57,1 \%$ ditentukan oleh faktor lain. Secara statistik dapat dinyatakan $r=0.67$. Hal ini sesuai dengan uji hipotesis menggunakan uji signifikansi korelasi, karena $t_{\text {hitung }}>t_{\text {tabel }}(5,1>$ 2,029) maka $\mathrm{H}_{\mathrm{o}}$ ditolak dan $\mathrm{H}_{\mathrm{i}}$ diterima. Sehingga Terdapat kontribusi yang positif dan signifikan penggunaan model pembelajaran tutorial berbasis articulate online terhadap aktifitas dan keterampilan siswa dalam perakitan komputer. 


\section{Kata Kunci :Model Pembelajaran Tutorial Articulate Online, Keterampilan Siswa, Perakitan Komputer}

\section{PENDAHULUAN}

\section{A. Latar Belakang}

Pembelajaran merupakan interaksi antara guru dan siswa dengan lingkungan belajar yang dirancang sedemikian rupa hingga mencapai tujuan pembelajaran, yaitu kemampuan yang diharapkan dimiliki oleh siswa setelah berlangsung proses pembelajaran. Hal tersebut sejalan dengan yang diungkapkan oleh Surya (2004:7) bahwa pembelajaran adalah suatu proses yang dilakukan oleh individu untuk memperoleh suatu perubahan perilaku yang baru secara keseluruhan sebagai hasil dari pengalaman individu itu sendiri dalam interaksi dengan lingkungan.

Selanjutnya, (Hamalik dalam Sanjaya 2009:6) menyatakan bahwa pembelajaran adalah suatu kombinasi yang tersusun meliputi unsur-unsur manusiawi, materil, fasilitas, perlengkapan, dan prosedur yang satu sama lain saling mempengaruhi untuk mencapai tujuan pembelajaran. Adapun yang dimaksud dengan unsur manusiawi yang terlibat dalam pembelajaran adalah terdiri atas siswa yang belajar, guru yang mengajar, dan staf atau tenaga lainnya yang turut membantu kelangsungan dan kelancaran proses pembelajaran dalam mencapai tujuan yang diharapkan, seperti tenaga laboratorium, staf administrasi, dan sebagainya. Sedangkan unsur material yang tercakup dalam pengertian pembelajaran adalah meliputi buku-buku, papan tulis, kapur, fotografi, slide dan film, serta audio dan video tape. Sementara yang termasuk fasilitas dan perlengkapan diantaranya adalah ruangan kelas dan perlengkapan audio visual termasuk komputer ataupun OHP (Over Head Projector). Adapun yang tergolong prosedur dalam pembelajaran adalah seperti jadwal dan metode penyampaian informasi, praktek, belajar, ujian, dan sebagainya.
Selain itu, hal-hal yang menunjang tumbuhnya keaktifan belajar siswa pada kegiatan belajar mengajar yakni adanya stimulus belajar, perhatian dan motivasi, respon, dan penguatan. Dalam pelaksanaanya di sekolah guru sering kali dihadapkan dengan bermacam-macam masalah, untuk itu guru diharapkan dapat menanggulangi setiap masalah yang timbul agar dapat mencapai tujuan pembelajaran. Di dalam praktek pembelajaran, permasalahan yang dihadapi yaitu penggunaan media pembelajaran yang kurang tepat dan kurang bervariasi.

Masalah lain dalam bidang pendidikan di Indonesia yang juga banyak diperbincangkan adalah bahwa dalam pembelajaran masih terlalu didominasi peran guru (teacher centered). Pembelajaran teacher centered berdampak terhadap rendahnya kemampuan peserta didik dalam mengontruksi/membangun pengetahuan sendiri dikarenakan peran guru sebagai satu-satunya sumber belajar. Sedangkan kemampuan peserta didik mengontruksi pengetahuannya sendiri merupakan kompetensi yang dituntut sesuai dengan yang diamanatkan dalam kurikulum 2013. Oleh sebab itu, diperlukan kepiawaian guru dalam merancang desain model pembelajaran yang dapat membantu siswa untuk belajar secara mandiri tidak terbatas hanya di ruang kelas. Keahlian guru untuk meramu sumber-sumber dan media belajar yang ada menjadi sebuah model pembelajaran yang dapat meningkatkan aktivitas dan keterampilan perakitan komputer.

Kegiatan praktikum perakitan komputer menerangkan mengenai bagaimana pengelolaan hardware komputer terdiri dari input device, output device, process device, dan peripheral device yang diintegrasikan dalam satu perangkat komputer dengan tujuan diharapkan siswa dapat menjelaskan dan memiliki keterampilan dalam pengelolaan 
perangkat keras/ Hardware komputer sehingga dapat mengoptimalkan kerja sistem komputer. Permasalahan yang muncul pada pembelajaran ini siswa menjadikan guru sebagai satu-satunya sumber belajar yang terbatas ruang dan waktu. Oleh sebab itu diperlukan perancangan model pembelajaran yang efektif untuk memfasilitasi belajar tanpa harus terbatas ruang dan waktu sehingga peserta didik dapat memperoleh pengetahuan kapanpun dan dimanapun.

Berdasarkan latar belakang masalah di atas, maka masalah utama yang ingin diketahui dirumuskan dalam pertanyaan berikut, " Kontribusi pembelajaran tutorial berbasis articulate online terhadap aktivitas dan keterampilan perakitan komputer."

\section{Rumusan Dan Batasan Masalah}

Berdasarkan latar belakang yang telah dikemukakan di atas, maka rumusan masalah dalam penelitian ini adalah:

1. Bagaimana penggunaan model pembelajaran tutorial berbasis articulate online kaitannya dengan pembelajaran?

2. Bagaimana keterampilan siswa dalam perakitan komputer?

3. Apakah terdapat kontribusi penggunaan model pembelajaran tutorial berbasis articulate online terhadap keterampilan siswa dalam perakitan komputer?

\section{Tujuan Penelitian}

Sesuai dengan perumusahan masalah di atas, maka penelitian ini bertujuan untuk mengetahui:

1. Penggunaan model pembelajaran tutorial berbasis articulate online dalam proses pembelajaran.

2. Keterampilan siswa dalam perakitan komputer pada praktikum perakitan komputer.

3. Kontribusi penggunaan model pembelajaran tutorial berbasis articulate online terhadap keterampilan siswa dalam perakitan komputer.

\section{Manfaat Penelitian}

Sesuai dengan permasalahan yang diteliti, maka manfaat dari penelitian ini adalah :

a) Dapat memberikan kontribusi keilmuan secara konseptual yang terkait dengan penggunaan model pembelajaran yang efektif dalam perkuliahan untuk meningkatkan keterampilan perakitan computer.

b) Sebagai sarana untuk mengetahui dan memecahkan masalah khususnya yang berkaitan dengan keterkaitan antara penggunaaan model pembelajaran tutorial.

c) Untuk memperoleh pengetahuan dan penambahan wawasan serta memberikan pengalaman langsung kepada peneliti untuk mengidentifikasi beberapa unsur dalam penggunaan model pembelajaran tutorial berkaitan keterampilan siswa.

\section{Hipotesis Penelitian}

Hipotesis dari penelitian ini adalah sebagai berikut:

Ho : "Tidak terdapat kontribusi penggunaan model pembelajaran tutorial berbasis articulate online terhadap keterampilan siswa dalam perakitan komputer.

$\begin{array}{rrr}\text { Ha } & \text { "Terdapat } & \text { kontribusi } \\ & \text { penggunaan } & \text { model } \\ & \text { pembelajaran } & \text { tutorial } \\ & \text { berbasis articulate online } \\ & \text { terhadap keterampilan siswa } \\ & \text { dalam perakitan komputer. }\end{array}$

\section{KAJIAN PUSTAKA}

\section{A. Multimedia Tutorial}

Tutorial secara definisi adalah pembelajaran khusus dengan instruktur yang terkualifikasi dan penggunaan mikrokomputer untuk tutorial secara khusus telah mencukupi. Tutorial dengan metode alternatif diantaranya bacaan, demonstrasi, penentuan bacaan atau pengalaman yang membutuhkan respon secara oral dan tulisan, serta adanya ujian (Darmawan, 2012: 139). 
Pembelajaran tutorial bertujuan untuk memberikan pemahaman secara tuntas kepada siswa mengenai materi atau bahan pembelajaran yang sedang dipelajari. Tutorial dalam program pembelajaran dengan bantuan komputer ditujukan sebagai pengganti manusia yang proses pembelajarannya diberikan melalui teks atau grafik pada layar yang menyediakan point-point pertanyaan atau permasalahan. Jika respon siswa benar maka komputer akan bergerak pada pembelajaran berikutnya, jika respon siswa salah komputer akan mengulangi pembelajaran sebelumnya atau bergerak pada salah satu bagian tertentu pembelajaran ulang, bergantung pada kesalahan yang dibuat.

Menurut Darmawan (2012: 140), ada beberapa tahapan pembelajaran dengan bantuan komputer model tutorial adalah sebagai berikut:

1. Penyajian informasi

2. Pertanyaan dan respon

3. Penilaian respon

4. Pemberian timbal balik respon

5. Pengulangan

6. Segmen pengaturan pelajaran

\section{B. Articulate}

Darmawan (2012: 137), software ini merupakan program yang dapat membantu para desainer pembelajaran modern berbasis digital mulai dari kalangan pemula hingga professional. Program articulate dapat dikatakan sebagai salah satu program aplikasi yang didukung oleh smart brainware secara sederhana dengan prosedur tutorial interaktif melalui template yang dapat dipublish secara offline maupun online sehinggan memudahkan user memformatnya dalam bentuk web personal, $\mathrm{CD}$, word processing dan Learning Management System ( LMS ).

Articulate engage merupakan program articulate yang paling mudah untuk dipelajari. Program pembelajaran yang dibangun dengan articulate engage ini bersifat tutorial, artinya bahwa pembelajaran bisa secara lengkap menyajikan prosedur pembelajaran yang cukup menarik, sederhana dan menantang interaktif para siswa. Program articulate engage ini dapat digunakan untuk mengembangkan beberapa logika atau alur pembelajaran mulai dari yang bertipe linier hingga brancing.

Program pembelajaran multimedia interaktif yang telah dibuat melalui articulate engage rasanya tidak sempurna jika tidak didampingi oleh beberapa instrument assessment hasil pembelajaran. Maka, untuk kepentingan membangun soal-soal dengan articulate ini dapat digunakan articulate quizmaker. Masih menurut Darmawan (2012: 163), program ini dikhususkan untuk membuat sejumlah soal dengan logika penambahan jumlah soal yang cukup mudah. Demikian juga dalam membangun logika untuk pertanyaan dan jawaban yang salah dan betul cukup mudah, serta sistem penskoran yang telah disediakan dan tinggal disetting untuk ketentuan interval/ skala nilainya.

\section{Perakitan Komputer}

Persiapan yang baik akan memudahkan dalam perakitan komputer serta menghindari permasalahan yang mungkin timbul.Hal yang terkait dalam persiapan meliputi:

a) Penentuan Konfigurasi Komputer Konfigurasi komputer berkait dengan penentuan jenis komponen dan fitur dari komputer serta bagaimana seluruh komponen dapat bekerja sebagai sebuah sistem komputer sesuai keinginan kita. Penentuan komponen dimulai dari jenis prosessor, motherboard, lalu komponen lainnya. Faktor kesesuaian atau kompatibilitas dari komponen terhadap motherboard harus diperhatikan, karena setiap jenis motherboard mendukung jenis prosessor, modul memori, port dan I/O bus yang berbeda-beda.

b) Persiapan Komponen dan Perlengkapan Komponen komputer beserta perlengkapan untuk perakitan dipersiapkan untuk perakitan 
dipersiapkan lebih dulu untuk memudahkan perakitan. Perlengkapan yang disiapkan terdiri dari:

Komponen komputer

$>$ Kelengkapan komponen seperti kabel, sekerup, jumper, baut dan sebagainya.

$>$ Buku manual dan referensi dari komponen

$>$ Alat bantu berupa obeng pipih dan philips

$>$ Software sistem operasi, device driver dan program aplikasi. Buku manual diperlukan sebagai rujukan untuk mengatahui diagram posisi dari elemen koneksi (konektor, port dan slot) dan elemen konfigurasi (jumper dan switch) beserta cara setting jumper dan switch yang sesuai untuk komputer yang dirakit. Diskette atau CD Software diperlukan untuk menginstall Sistem Operasi, device driver dari piranti, dan program aplikasi pada komputer yang selesai dirakit.

c) Pengamanan

Tindakan pengamanan diperlukan untuk menghindari masalah seperti kerusakan komponen oleh muatan listrik statis, jatuh, panas berlebihan atau tumpahan cairan.Pencegahan kerusakan karena listrik statis dengan cara:

$>$ Menggunakan gelang anti statis atau menyentuh permukaan logam pada casing sebelum memegang komponen untuk membuang muatan statis.

$>$ Tidak menyentuh langsung komponen elektronik, konektor atau jalur rangkaian tetapi memegang pada badan logam atau plastik yang terdapat pada komponen.

Tahapan proses pada perakitan komputer terdiri dari:
a) Penyiapan motherboard
b) Memasang Prosessor
c) Memasang heatsink
d) Memasang Modul Memori

e) Memasang Motherboard pada Casing

f) Memasang Power Supply

g) Memasang Kabel Motherboard dan Casing

h) Memasang Drive

i) Memasang card Adapter

j) PenyelesaianAkhir

\section{Aktivitas dan Hasil Belajar Siswa}

Yang dimaksud aktivitas adalah segala perbuatan yang disengaja dirancang oleh guru untuk memfasilitasi kegiatan belajar siswa seperti kegiatan diskusi, demonstrasi, simulasi, melakukan percobaan dan lain sebagainya (Sanjaya, 2011: 176). Masih menurut Sanjaya, belajar bukanlah menghafal sejumlah fakta atau informasi. Belajar adalah berbuat, memperoleh pengalaman tertentu sesuai dengan tujuan yang diharapkan. Karena itu, strategi pembelajaran harus dapat mendorong aktivitas siswa. Aktivitas tidak dimaksudkan terbatas pada aktivitas fisik, akan tetapi juga meliputi aktivitas yang bersifat psikis seperti aktivitas mental (Sanjaya, 2011: 132).

Sanjaya menguraikan beberapa asumsi perlunya pembelajaran berorientasi aktivitas siswa (2011: 135-136):

1. Asumsi filosofis tentang pendidikan. Hakikat pendidikan pada dasarnya adalah:
a. Interaksi manusia
b. Pembinaan dan pengembangan potensi manusia
c. Berlangsung sepanjang hayat
d. Kesesuaian dengan kemampuan dan tingkat perkembangan siswa
e. Keseimbangan antara kebebasan subyek didik dan kewibawaan guru
f. Peningkatan kualitas hidup manusia

2. Asumsi tentang siswa sebagai subyek pendidikan, yaitu:
a. Siswa bukanlah manusia dalam ukuran mini, akan tetapi manusia yang sedang dalam tahap perkembangan
b. Setiap manusia mempunyai kemampuan yang berbeda


c. Anak didik pada dasarnya adalah insan yang aktif, kreatif dan dinamis dalam menghadapi lingkungannya.

d. Anak didik memiliki motivasi untuk memenuhi kebutuhannya

3. Asumsi tentang guru adalah:

a. Guru bertanggungjawab atas tercapainya hasil belajar peserta didik

b. Guru memiliki kemampuan profesional dalam mengajar

c. Guru mempunyai kode etik keguruan

d. Guru memiliki peran sebagai sumber belajar, pemimpin (organisator) dalam belajar yang memungkinkan terciptanya kondisi yang baik bagi siswa dalam belajar.

4. Asumsi yang berkaitan dengan proses pengajaran adalah:

a. Bahwa proses pengajaran direncanakan dan dilaksanakan sebagai suatu sistem

b. Peristiwa belajar akan terjadi manakala anak didik berinteraksi dengan lingkungan yang diatur oleh guru

c. Proses pengajaran akan lebih aktif apabila menggunakan metode dan teknik yang tepat dan berdaya guna

d. Pengajaran memberikan tekanan kepada proses dan produk secara seimbang

e. Inti proses pengajaran adalah adanya kegiatan belajar siswa secara optimal.

Hasil belajar siswa pada hakikatnya adalah perubahan tingkah laku. Tingkah laku sebagai hasil belajar dalam pengertian luas mencakup bidang kognitif, afektif dan psikomotor. Peranan tujuan instruksional atau tujuan pembelajaran yang berisi rumusan kemampuan dan tingkah laku yang diinginkan dikuasai siswa menjadi unsur penting sebagai dasar dan acuan penilaian hasil belajar (Sudjana, 2009: 3).

Mengenai hasil belajar, Benyamin S. Bloom, dkk (dalam Arifin, 2011: 92), mengelompokkan dalam tiga domain, yaitu: (a) domain kognitif, meliputi pengetahuan, pemahaman, penerapan, analisis, sintesis dan evaluasi (b) domain afektif, meliputi penerimaan, respon, penilaian, organisasi, karakterisasi dan (c) domain psikomotor, yang meliputi persepsi, kesiapan melakukan suatu pekerjaan, respon terbimbing, kemahiran, adaptasi dan orijinasi

\section{METODE PENELITIAN}

Metode yang digunakan dalam penelitian ini adalah metode kuantitatif. Jenis penelitian adalah penelitian korelasional yang mana penelitian ini bertujuan untuk menyelidiki variasi yang dimiliki suatu faktor berhubungan dengan variasi pada faktor - faktor lainnya pada satu kelompok subjek yang didasarkan pada koefisien korelasi, atau dengan kata lain untuk menentukan ada tidaknya kontribusi penggunaan model pembelajaran tutorial berbasis articulate online terhadap aktivitas dan keterampilan perakitan komputer.

Populasi dalam penelitian ini adalah siswa kelas $\mathrm{X}-1$ jurusan TKJ SMK Al-Fari Tahun 2014/2015. Penelitian ini dilakukan terhadap sebagian populasi yang disebut sampel. Sampel yang digunakan dalam penelitian diambil satu kelas dengan menggunakan teknik Cluster Random Sampling.

Instrumen yang dipergunakan untuk memperoleh data sesuai dengan tujuan dan permasalahan penelitian adalah dengan menggunakan teknik komunikasi secara tertulis berupa angket tes dan objektif.

a. Skala sikap dengan menggunakan skala Likert dengan 5 alternatif jawaban untuk mengukur pandangan siswa terhadap penggunaan model pembelajaran tutorial berbasis articulate online pada perakitan komputer

b. Instrumen yang digunakan dalam penelitian ini berupa tes objektif dalam pilihan ganda dengan 4 
alternatif jawaban dan tes menjodohkan yang berisi tes mengenai pada perakitan komputer.

Langkah - langkah dalam uji coba instrumen adalah sebagai berikut:

a. Menguji validitas instrumen penelitian.

b. Uji Relibilitas Instrumen

Instrument diujicobakan terlebih dahulu agar dihasilkan instrumen yang benar - benar layak digunakan untuk penelitian. Setelah diujicobakan maka instrumen dianalisis sebagai yaitu, a) validitas butir soal, b) nilai reliabilitas, c) tingkat kesukaran, dan d) daya pembeda

Dalam pelaksanaan penelitian ini dilakukan dalam 3 tahapan, yaitu : a) Persiapan, b) pelaksanaan, dan c) Pengolahan Data. Serta teknik analisis data dalam penelitian ditujukan untuk memperoleh data yang lebih bermakna dalam menjawab masalah - masalah penelitian yang telah dirumuskan. Dengan demikian untuk keperluan tersebut digunakan statistik dalam pengolahan dan penganalisisan, yaitu a) uji distribusi normalitas dan b) uji hipotesis.

\section{HASIL PENELITIAN DAN PEMBAHASAN \\ A. Hasil Analisis Data Uji Coba Instrumen}

Dari hasil uji validitas variabel $\mathrm{X}$ diperoleh 20 item yang diterima (valid) dan memenuhi syarat dalam tingkat kepercayaan $95 \%$ dan 5 item yang ditolak (tidak valid), maka item yang ditolak atau tidak valid tidak digunakan dalam penelitian, sehingga instrumen variabel $\mathrm{X}$ yang digunakan dalam penelitian berjumlah 20 item. Untuk perhitungan reliabilitas skala sikap diperoleh $\mathrm{r}_{\text {hitung }}$ sebesar 0,8 dan $r_{\text {tabel }}$ sebesar 0,36 dalam tingkat kepercayaan 95\%. Berdasarkan kriteria dari Arikunto (2005 : 100), koefisien dalam interval 0,80-1,00 tergolong kategori sangat tinggi. Setelah dilakukan antara $r_{\text {hitung }}$ dan $r_{\text {tabel, }}$ ternyata $r_{\text {hitung }}(0,85)>r_{\text {tabel }}(0,36)$, dengan demikian instrumen skala sikap tersebut dinyatakan reliabel.

Sedangkan analisis soal uji coba variabel $\mathrm{Y}$ dengan bentuk pilihan ganda dan menjodohkan sebanyak 40 soal dilakukan dengan menguji tingkat kesukaran, daya pembeda, validitas, dan reliabilitas soal. Analisis butir soal diperlukan untuk mengetahui kekuatan dan kelemahan butir tes.

Dari hasil uji tingkat kesukaran, daya pembeda dan validitas soal diperoleh 25 soal yang layak digunakan dalam penelitian setelah melalui beberapa seleksi dan revisi. Dari perhitungan reliabilitas tes, diperoleh nilai reliabilitas tes sebesar 0,5. Berdasarkan kriteria dari Arikunto (2005 : 100), koefisien dalam interval 0,40-0,60 tergolong kategori cukup. Hal ini berarti instrumen tersebut memiliki kriteria cukup untuk alat pengumpul data, sehingga diharapkan mampu mengungkap data yang dapat dipercaya pula.

\section{Hasil Analisis Data Penelitian}

Sampel dalam penelitian ini berjumlah 38 orang siswa kelas X-1 AlFarizi. Pengumpulan data dilakukan dengan skala sikap (angket) untuk mengetahui mengukur penggunaan model pembelajaran tutorial berbasis articulate online dan tes objektif (post test) untuk mengetahui keterampilan siswa pada perakitan komputer.

a. Penggunaan model pembelajaran tutorial berbasis articulate online

Berikut ini adalah data hasil perhitungan :

Tabel 4.1

a. Data Hasil Angket Penggunaan model pembelajaran tutorial berbasis articulate online

\begin{tabular}{|l|l|}
\hline $\begin{array}{l}\text { Nominasi } \\
\text { Statistika }\end{array}$ & Skor \\
\hline Min & 50 \\
\hline Max & 76 \\
\hline N & 38 \\
\hline X & 64,47 \\
\hline
\end{tabular}




\section{SD} 6,21

Rentang skor hasil belajar siswa yang menggunakan model pembelajaran tutorial berbasis articulate online dalam penelitian ini adalah 50-76, yang berarti skor terendah yang berhasil di capai sebesar 50 dan skor tertingginya 76 . Sedangkan rata-rata skor yang diperoleh sebesar 63,47 (85\%) dengan standar deviasi sebesar 6,2. Dari hasil tersebut tampak bahwa penggunaan model pembelajaran tutorial berbasis articulate online dapat dikatagorikan "baik sekali" karena $85 \%$ berada ada interval $80-100$ (Arikunto, 2005 : 251).

\section{b. Keterampilan Siswa Dalam Perakitan Komputer}

Berikut ini adalah data hasil perhitungan terhadap data tes untuk memperoleh informasi hasil belajar siswa.

Tabel 4.2

Data Hasil Belajar (Tes Objektif)

\begin{tabular}{|l|l|}
\hline $\begin{array}{l}\text { Nominasi } \\
\text { Statistika }\end{array}$ & Skor \\
\hline Min & 10 \\
\hline Max & 27 \\
\hline N & 38 \\
\hline X & 17,79 \\
\hline SD & 3,10 \\
\hline
\end{tabular}

Rentang skor hasil belajar adalah 10-27, yang berarti skor terendah yang berhasil di capai sebesar 10 dan skor tertingginya 27 . Sedangkan rata-rata skor yang diperoleh sebesar 18,79 (72\%) dengan standar deviasi sebesar 3,18 dapat dikatakan "baik' karena $71 \%$ berada ada interval $60-80$ (Arikunto, 2005 : 251).

C. Kontribusi Penggunaan Model Pembelajaran Tutorial Berbasis Articulate Online Terhadap Aktivitas dan Keterampilan Perakitan Komputer

Kontribusi Penggunaan Model Pembelajaran Berbasis Articulate Online Terhadap Aktivitas dan Keterampilan Perakitan Komputer dapat diketahui dengan menganalisis data-data yang telah diperoleh, setelah menganalisis data, maka dapat dihitung ukuran-ukuran statistikanya meliputi:

\section{1) Normalitas Data}

Pengujian normalitas data ditujukan untuk mengetahui apakah data berdistribusi normal atau tidak, sehingga dapat menentukan uji statistika yang digunakan. Rumus yang digunakan untuk pengujian normalitas data adalah uji chi-kuadrat.

\section{a) Uji Normalitas Penggunaan} Model Pembelajaran Tutorial Berbasis Articulate Online

Dari hasil perhitungan uji normalitas penggunaan model pembelajaran tutorial (perhitungan terlampir) diperoleh $\chi_{\text {hitung }}^{2}=7,78$ sedangkan chi-kuadrat tabel diperoleh $\chi_{(0,95)(3)}^{2}=7,81$. Ternyata $\chi_{\text {hitung }}^{2}(7,78)$ $<\chi_{\text {tabel }}^{2}(7,81)$ maka penyebaran angket berdistribusi normal pada tingkat kepercayaan $95 \%$.

Tabel 4.3

Hasil Uji Normalitas Angket

\begin{tabular}{|l|l|l|l|}
\hline Dk & $\chi_{\text {hitung }}^{\mathbf{n}}$ & $\chi_{\text {tabel }}$ & Keterangan \\
\hline 3 & 7,78 & 7,81 & Normal \\
\hline
\end{tabular}

b) Uji Normalitas Keterampilan Siswa Dalam Perakitan Komputer

Dari hasil perhitungan uji normalitas keterampilan siswa pada diperoleh $\chi_{\text {hitung }}^{2}=3,8$ sedangkan chi-kuadrat tabel diperoleh $\chi^{2}$ $(0,95)(3)=7,81$. Ternyata $\chi^{2}$ hitung $(3,8)$ $<\chi_{\text {tabel }}^{2}(7,81)$ maka penyebaran skor skala sikap berdistribusi normal pada tingkat kepercayaan $95 \%$.

\section{Tabel 4.4}

\section{Hasil Uji Normalitas Hasil Belajar}

\begin{tabular}{|l|l|l|l|}
\hline Dk & $\chi^{\mathbf{2}}{ }_{\text {hitung }}$ & $\chi_{\text {tabel }}{ }$ & Keterangan \\
\hline 3 & 3,8 & 7,81 & Normal \\
\hline
\end{tabular}




\section{2) Uji Hipotesis}

a) Menentukan persamaan regresi dari kedua variabel dengan rumus :

$$
\begin{gathered}
y=a+b x \text { dengan } \\
\frac{\left(\sum x^{2}\right)\left(\sum y\right)-\left(\sum x\right)\left(\sum x y\right)}{n\left(\sum x^{2}\right)-\left(\sum x\right)^{2}} \\
b=\frac{n\left(\sum x y\right)-\left(\sum x\right)\left(\sum y\right)}{n\left(\sum x^{2}\right)-\left(\sum x\right)^{2}}
\end{gathered}
$$

Agar $a$ dan $b$ pada persamaan regresi dapat ditentukan, maka terlebih dahulu ditentukan beberapa harga yang diperlukan (perhitungannya terlampir)

$\begin{array}{rll}\mathrm{x} & = & 2458 \\ \mathrm{y} & = & 676 \\ \mathrm{x}^{2} & = & 160450 \\ \mathrm{y}^{2} & = & 12392 \\ \left(\mathrm{x}^{2}\right)^{2} & = & 6041764 \\ \left(\mathrm{y}^{2}\right)^{2} & = & 456976 \\ \mathrm{xy} & = & 44192 \\ \mathrm{n} & = & 38\end{array}$

Selanjutnya harga - harga tersebut disubtitusikan pada rumus di atas, sehingga diperoleh harga $a=2,89$ dan harga $b=0,32$

Jadi persamaan regresinya adalah : $y=2,89+0,32 x$

\section{b) Uji Linieritas Regresi}

Uji ini dimaksudkan untuk mengetahui tingkat kelinieran antara penggunaaan model pembelajaran tutorial berbasis articulate online terhadap aktivitas dan keterampilan siswa dalam perakitan komputer. Hasil uji linieritas dapat ditabulasikan kedalam tabel sebagai berikut :

Tabel 4.5

Hasil Uji Linieritas

\begin{tabular}{|l|l|}
\hline Keterangan & Skor \\
\hline Persamaan regresi & $y=2,89+0,32 x$ \\
\hline$d b_{t c}$ & 15 \\
\hline$d b_{k k}$ & 21 \\
\hline Ftc & $-9,93$ \\
\hline
\end{tabular}

\begin{tabular}{|l|l|}
\hline$F_{\text {tabel }}$ & 0,2315 \\
\hline
\end{tabular}

Dari tabulasi di atas tampak Ftc < $F_{\text {tabel }}(-9,83<0,2315)$ maka regresinya dinyatakan linier, oleh karena itu telah dalam penelitian ini memenuhi syarat untuk menggunakan statistika parametrik dalam hal ini menggunakan product momen.

\section{c) Uji Koefisien Korelasi}

Pengujian koefisien korelasi dimaksudkan untuk melihat kontribusi antara dua hasil pengukuran atau dua variabel yang diteliti. Selanjutnya untuk mengetahui kontribusi yang berarti antara penggunaan model pembelajaran tutorial terhadap aktifitas dan keterampilan siswa pada perakitan komputer.

Berdasarkan hasil perhitungan diperoleh koefisien korelasi (r) sebesar 0,64 , yang berarti bahwa terdapat kontribusi penggunaan model pembelajaran tutorial terhadap aktifitas dan keterampilan siswa pada perakitan komputer. Adapun arti besarnya koefisien korelasi, yakni terdapat korelasi yang tinggi atau kuat (Hasil perhitungan dan keterangannya dapat dilihat pada lampiran). Hal ini sesuai dengan koefisien korelasi yang digolongkan sebagai berikut:

\section{d) Uji Signifikansi Korelasi}

Dari perhitungan korelasi di atas diketahui koefisien kolerasi sebesar 0,67. maka dapat diperoleh $t_{\text {hitung }}$ sebesar 5,1 . Sedangkan untuk $t_{\text {tabel }}$ dengan derajat kebebasan 36 (38-2) pada taraf kepercayaan 95\% sebesar 2,029; dengan demikian $t_{\text {hitung }}>t_{\text {tabel }}(5,1>2,029)$ maka $\mathrm{H}_{\mathrm{o}}$ ditolak dan $\mathrm{H}_{\mathrm{i}}$ diterima. Dengan kata lain artinya terdapat kontribusi yang signifikan atau berarti penggunaan penggunaan model pembelajaran tutorial berbasis articulate online terhadap aktifitas dan keterampilan siswa pada perakitan komputer.

e) Uji Koefisien Determinasi

Dari hasil perhitungan koefisien determinasi diperoleh sebesar 42,9\%, yang berarti penggunaan model 
pembelajaran tutorial berbasis articulate online terhadap aktifitas dan keterampilan siswa pada perakitan komputer sebesar $42,9 \%$, sisanya $(57,1 \%)$ ditentukan oleh variabel lain.

\section{B. Pembahasan}

Berdasarkan hasil pengujian hipotesis yang telah dilakukan melalui uji statistik, dinyatakan bahwa penggunaan model pembelajaran tutorial berbasis articulate online mempunyai kontribusi terhadap terhadap aktifitas dan keterampilan siswa pada perakitan komputer. Dengan demikian model pembelajaran tutorial berbasis articulate online merupakan salah satu faktor yang menentukan hasil belajar siswa dan memberikan kontribusi terhadap hasil belajar siswa kearah yang lebih baik.

Gambaran lebih lanjut mengenai hasil penelitian tersebut diuraikan dalam pembahasan berikut :

\section{Penggunaan Model Pembelajaran Tutorial Berbasis Articulate Online Pada Pembelajaran}

Berdasarkan hasil penelitian menunjukkan bahwa penggunaan model pembelajaran tutorial berbasis articulate online terhadap aktivitas dan keterampilan perakitan komputer memiliki kontribusi yang "sangat baik", karena skor rata-rata yang diperoleh $63,47(85 \%)$ berada ada interval $80-$ 100 artinya penggunaan model pembelajaran tutorial berbasis articulate online dapat memberikan kontribusi yang sangat baik dalam proses belajar mengajar sehingga membantu guru dan siswa menuju proses belajar mengajar yang lebih baik dan menyenangkan. Model pembelajaran tutorial berbasis articulate online sangat dibutuhkan dalam proses pembelajaran karena dapat membantu para siswa untuk meningkatkan perhatiannya terhadap materi pembelajaran sehingga meningkatkan hasil belajar siswa. Oleh karena itu, guru diharapkan dapat merancang dan mendesain model pembelajaran multimedia tutorial yang dapat membuat suasana belajar menjadi menyenangkan, sehingga tujuan pembelajaran yang telah ditetapkan dapat tercapai.

Pembelajaran multimedia pada dasarnya merupakan pembelajaran yang diharapkan mampu memberdayakan semua aktivitas otak selama siswa melakukan aktivitas pembelajaran dan diharapkan pula dapat memfasilitasi semua gaya belajar siswa, baik audio, visual maupun gaya belajar kinestetik. Darmawan (2012: 55) memaparkan beberapa karakteristik pembelajaran berbasis multimedia yaitu :

a) Berisi konten materi yang representative dalam bentuk visual, audio, audiovisual.

b) Beragam media komunikasi dalam penggunaannya.

c) Memiliki kekuatan bahasa warna dan bahasa resolusi objek.

d) Tipe - tipe pembelajaran yang bervariasi.

e) Respon pembelajaran dan penguatan bervariasi.

f) Mengembangkan prinsip self evaluation dalam mengukur proses dan hasil belajarnya.

g) Dapat digunakan secara klasikal atau individual.

h) Dapat digunakan secara offline maupun online.

Pengadaan media teknologi informasi dan komunikasi untuk pembelajaran dapat juga berasal dari sekolah itu sendiri atau dari pihak lain. Pada dasarnya tidak menjadi masalah dari manapun asalnya, yang paling penting adalah bagaimana menyiasati agar media (TIK) tersebut yang ada di sekolah dapat dimanfaatkan secara optimal untuk kepentingan pembelajaran peserta didik. Beberapa contoh media TIK yang banyak tersedia diantaranya CD / Kaset Audio, VCD, DVD, LCD, komputer dan Internet, termasuk pembelajaran tutorial berbasis multimedia articulate ini. 


\section{Keterampilan Siswa Dalam Perakitan Komputer}

Hasil penelitian menunjukan bahwa keterampilan siswa pada perakitan komputer dengan menggunakan model pembelajaran tutorial berbasis articulate online memiliki kontribusi baik, karena skor rata-rata yang diperoleh $18,79(72 \%)$ berada pada interval $60-80$ artinya bahwa memberi kesempatan pada siswa untuk aktif dalan proses belajar mengajar yang menarik atau bervariasi dapat meningkatkan hasil belajar siswa kearah yang lebih baik.

Salah satu tugas pokok guru ialah mengevaluasi taraf keberhasilan rencana dan pelaksanaan kegiatan belajar mengajar. Surya (2004:53) mengemukakan bahwa guru berperan sebagai penilai hasil belajar siswa (evaluator of student learning). Sebagai perancang pengajaran (manager of intruction), seorang guru berperan mengelola seluruh proses belajar mengajar dengan menciptakan kondisikondisi belajar sedemikian rupa sehingga setiap anak dapat belajar secara efektif dan efisien. Untuk melihat sejauh mana keberhasilan mengajar guru dan belajar peserta didik secara tepat, kita memerlukan informasi yang didukung oleh data yang objektif dan memadai tentang indikatorindikator perubahan perilaku dan pribadi peserta didik. Informasi yang diperoleh melalui evaluasi ini akan merupakan umpan balik terhadap proses kegiatan belajar mengajar yang selanjutnya akan dijadikan titik tolak untuk memperbaiki dan meningkatkan proses belajar mengajar selanjutnya. Dengan demikian, proses belajar mengajar akan senantiasa ditingkatkan terus menerus untuk memperoleh hasil belajar yang optimal.

Menurut Sudjana (2004 : 3) hasil belajar pada hakikatnya adalah perubahan tingkah laku setelah menempuh pengalaman belajar. Hasil belajar merupakan tingkah laku yang diamati pada keterampilan seseorang yang merupakan bukti dari adanya proses belajar yang beraneka ragam. Dalam sistem pendidikan nasional, hasil rumusan tujuan pendidikan, tujuan kurikuler maupun tujuan instruksional menggunakan klasifikasi hasil belajar dari Bloom dalam Sudjana (2004 : 22). Tujuan instruksional itu sendiri pada hakikatnya merupakan rumusan kemampuan yang diharapkan bisa dimiliki atau dapat dikuasai setelah menempuh proses belajar mengajar.

Hasil belajar menurut Bloom bahwa hasil belajar dapat dimanipestasikan dalam wujud perubahan aspek kognitif, afektif dan psikomotorik. Hasil belajar belum dikatakan lengkap apabila hanya menghasilkan perubahan satu aspek saja akan tetapi harus mencakup perilaku lainnya yang meliputi aspek kognitif (pengetahuan), aspek afektif (sikap), dan aspek psikomotorik (keterampilan) (Surya 2004:17). Dalam melakukan penilaian hasil belajar hendaknya mencakup seluruh perubahan perilaku itu. Sehubungan dengan penilitian yang dilakukan telah ditemukan ketercapaian perubahan tingkah laku siswa pada beberapa aspek, yaitu aspek kognitif ditandai dengan siswa bisa memahami nama perangkat komponen hardware, aspek afektif ditandai dengan siswa dapat mengetahui cara-cara memasangkan komponen harware dalam motherboard, serta aspek psikomotorik ditandai dengan terampilnya melakukan prosedur praktikum dengan ditunjang alat sehingga dapat merakit komputer.

Untuk mengukur keterampilan siswa maka diperlukan tes. Tes merupakan alat ukur yang digunakan untuk mengukur keberhasilan siswa mencapai kompetensi. Tes memiliki peranan yang cukup penting dalam proses pembelajaran. Dalam mengukur hasil belajar setelah pembelajaran 
dilaksanakan tes yang juga memiliki banyak kegunaan, terutama dalam melihat keberhasilan pembelajaran dan pembentukan kompetensi.

Proses penilaian terhadap hasil belajar dapat memberikan informasi kepada guru tentang kemajuan siswa dalam upaya mencapai tujuan-tujuan belajarnya melalui kegiatan belajar. Selanjutnya dari informasi tersebut guru dapat menyusun dan membina kegiatankegiatan siswa lebih lanjut, baik untuk keseluruhan kelas maupun individu.

Belajar adalah suatu perubahan perilaku, akibat interaksi dengan lingkungannya" (Ali Muhammad, 2004 : 14). Perubahan perilaku dalam proses belajar terjadi akibat dari interaksi dengan lingkungan. Interaksi biasanya berlangsung secara sengaja. Dengan demikian belajar dikatakan berhasil apabila terjadi perubahan dalam diri individu. Sebaliknya apabila terjadi perubahan dalam diri individu maka belajar tidak dikatakan berhasil.

Kualitas pengajaran yang dimaksud adalah profesional yang dimiliki oleh guru. Artinya kemampuan dasar guru baik di bidang kognitif (intelektual), bidang sikap (afektif) dan bidang perilaku (psikomotorik). Dari beberapa pendapat di atas maka hasil belajar siswa dipengaruhi oleh dua faktor dari dalam individu siswa berupa kemampuan personal (internal) dan faktor dari luar diri siswa yakni lingkungan. Dengan demikian hasil belajar adalah sesuatu yang dicapai atau diperoleh siswa berkat adanya usaha atau fikiran yang mana hal tersebut dinyatakan dalam bentuk penguasaan, pengetahuan dan kecakapan dasar yang terdapat dalam berbagai aspek kehidupa sehingga nampak pada diri indivdu penggunaan penilaian terhadap sikap, pengetahuan dan kecakapan dasar yang terdapat dalam berbagai aspek kehidupan sehingga nampak pada diri individu perubahan tingkah laku secara kuantitatif.

\section{Kontribusi Penggunaan Model}

\section{Pembelajaran Tutorial Berbasis \\ Articulate Online Terhadap \\ Keterampilan Siswa Dalam \\ Perakitan Komputer}

Berdasarkan hasil penelitian, menunjukan terdapat kontribusi yang signifikan penggunaan model pembelajaran tutorial berbasis articulate online terhadap aktifitas dan keterampilan siswa. Hal ini dapat dilihat dari hasil perhitungan koefesien korelasi sebesar 0,67 dimana $t_{\text {hitung }}>t_{\text {tabel }}(5,1>2,029)$ sedangkan kontribusi yang diberikan sebesar $42,9 \%$.

\section{KESIMPULAN}

Dari hasil penelitian yang telah penulis lakukan mulai dari pengumpulan data, pengolahannya hingga sampai pengujian hipotesis, yang telah penulis lampirkan pada Bab IV, maka pada bagian ini akan dibahas secara berturut-turut temuan pokok atau kesimpulan

Berdasarkan hasil pembahasan pada bab IV maka dapat ditarik kesimpulan sebagai berikut :

1. Penggunaan model pembelajaran tutorial berbasis articulate online adalah baik sekali, karena skor ratarata yang diperoleh $63,47 \quad(85 \%)$ berada ada interval $80-100$ artinya penggunaan model pembelajaran tutorial berbasis articulate online dapat memberikan kontribusi yang sangat baik dalam proses belajar mengajar sehingga membantu guru dan siswa menuju proses belajar mengajar yang lebih baik dan menyenangkan.

2. Keterampilan siswa yang menggunakan model pembelajaran tutorial berbasis articulate online adalah baik, karena skor rata-rata yang diperoleh $18,79(72 \%)$ berada pada interval $60-80$ artinya bahwa memberi kesempatan pada siswa untuk aktif dalam proses belajar mengajar dengan menggunakan model pembelajaran mengajar yang menarik atau bervariasi dapat meningkatkan 
keterampilan siswa kearah yang lebih baik.

3. Besarnya kontribusi penggunaaan model pembelajaran tutorial berbasis articulate online terhadap aktifitas dan keterampilan perakitan komputer adalah 42,9\%, sisanya sebanyak $57,1 \%$ ditentukan oleh faktor lain. Secara statistik dapat dinyatakan $\mathrm{r}=$ 0.67. Hal ini sesuai dengan uji hipotesis menggunakan uji signifikansi korelasi, karena $t_{\text {hitung }}>$ $\mathrm{t}_{\text {tabel }}(5,1>2,029)$ maka $\mathrm{H}_{\mathrm{o}}$ ditolak dan $\mathrm{H}_{\mathrm{i}}$ diterima. Sehingga Terdapat kontribusi yang positif dan signifikan penggunaan model pembelajaran tutorial berbasis articulate online terhadap aktifitas dan keterampilan perakitan komputer.

\section{B. REKOMENDASI}

Berdasarkan hasil penelitian dan kesimpulan diatas maka penulis mencoba memberikan rekomendasi kepada beberapa pihak yang dapat dijadikan bahan pertimbangan dalam meningkatkan keterampilan belajar siswa dalam perakitan komputer.

\section{Bagi Sekolah}

a. Kemudahan kepada siswa dalam menggunakan sarana dan prasarana sekolah dapat menumbuhkan minat siswa.

b. Melengkapi perlengkapan yang menunjang pada kelancaran proses belajar mengajar.

2. Bagi Guru

a. Dengan memilih dan menggunakan model pembelajaran yang tepat, yang sesuai dengan pokok bahasan dan dapat memberi kesempatan kepada siswa untuk terlibat aktif dalam pembelajaran.

b. Dengan sering mengajak siswa atau menyertakan kegiatan praktikum pada konsep-konsep yang memerlukan penjelasan melalui praktikum, dapat membuat siswa tidak asing dengan kegiatan praktikum dan peralatan praktikum. c. Sebelum melaksanakan proses belajar mengajar, hendaknya memperhatikan dengan baik penyediaan bahan dan media/peralatan yang akan digunakan, baik dari segi jumlah maupun kondisi peralatan tersebut.

d. Mempertimbangkan dan menguasai materi dan peralatan yang akan digunakan dalam demontrasi materi yang akan diperagakan dapat dengan mudah dipahami oleh siswa.

e. Dengan memperhatikan pengelolaan atau pengalokasian waktu dengan tepat pada saat pelaksanaan penggunaan model pembelajaran tutorial sehingga semua tahapan pembelajaran dapat dilaksanakan.

3. Bagi Siswa

a. Sering mencoba mengoperasikan komponen-komponen harware, sehingga pada saat penilaian kinerja siswa tidak gugup dan sudah terampil dengan demikian kinerja yang ditampilkan menjadi baik.

\section{DAFTAR PUSTAKA}

Ali, Mohammad. (2002). Guru Dalam Proses Belajar Mengajar. Bandung: Sinar Baru Algensindo.

Arikunto, S. (2005). Dasar - Dasar Evaluasi Pendidikan. Jakarta: Bumi Aksara.

(2006). Prosedur Penelitian

Suatu Pendekatan Praktik. Jakarta: Rineka Cipta

Darmawan, Deni (2012)., Inovasi Pendidikan: Pendekatan Praktik Teknologi Multimedia dan Pembelajaran Online. Bandung: PT Remaja Rosdakarya.

Nurgana, E. (1998). Statistika untuk Penelitian. Bandung: CV. Permai

Sanjaya, Wina. (2011). Strategi Pembelajaran Berorintasi Standar Proses Pendidikan. Jakarta: Kencana Prenada Media. 

. (2009). Perencanaan dan Desain Sistem Pembelajaran. Jakarta: Kencana Prenada Media.

Semiawan, C, et all. (1988). Pendekatan Keterampilan Proses : Bagaimana Mengaktifkan Siswa dalam Belajar. Jakarta: PT Gramedia.

Sudjana, N. (1990). Penilaian Hasil Proses Belajar Mengajar. Bandung: Remaja Rosda Karya.

Bandung: Tarsito. (1992). Metode Statistik. (2002). Dasar - Dasar Proses Belajar Mengajar. Bandung: Sinar Baru Algensindo.

(2009). Dasar - Dasar Proses Belajar Mengajar. Bandung: Sinar Baru Algensindo

Surya, M. (2004). Psikologi Pembelajaran dan Pengajaran. Bandung: Pustaka Bani Quraisy.

Sutikno, S. (2005). Pembelajaran Efektif. Mataram: NTP Press.

Wahab, A.A. (2007). Metode dan Model Model Mengajar. Bandung: Alfabeta 